\title{
Salicylic acid in the induction of resistance to beet seedling damping-off and antifungal activity against Fusarium sp., in vitro
}

\author{
Ácido salicílico na indução de resistência ao tombamento de \\ plântulas de beterraba e atividade antifúngica contra \\ Fusarium sp., in vitro
}

\author{
Douglas Junior Bertoncelli ${ }^{1}$; Sérgio Miguel Mazaro²*; \\ Rita de Cassia Dosciatti Serrão Rocha ${ }^{1}$; Nean Locatelli Dalacosta ${ }^{3}$; \\ Adriano Lewandowski³; Américo Wagner Junior ${ }^{2}$
}

\begin{abstract}
The damping off is the main disease that affects the beet crop during the seedling production. The aim of this study was to evaluate different salicylic acid (SA) concentrations for resistance induction against damping-off in beet seedling and its antifungal activity against Fusarium sp., in vitro condition. Treatment of beet seed was with SA solution by immersion during 5 minutes in the $0.5,1.0,1.5$ and $2.0 \mathrm{mM}$ concentrations and control (distilled water). It was used four replications with 20 cells by experimental unit. The experiment was carried out for 14 days in cultivate chamber with temperature $\left(23{ }^{\circ} \mathrm{C} \pm 2{ }^{\circ} \mathrm{C}\right)$, lighting ( 12 hours photoperiod) and humidity $(70 \% \pm 10 \%)$ controlled. After this time, the germination, damping off incidence, seedling length and fresh mass matter weight were evaluated. It was evaluated also in the seedling tissue the phenylalanine ammonia-lyase (PAL), $\beta-1.3$ glucanase and chitinase level enzymes. In the in vitro the SA was putted in PDA (potato-dextrose-agar) medium, where the Fusarium sp. mycelial growth was evaluated. The SA applied for seeds treatment didn't had effect significant on damping off of beet seedlings, but it induced the activity of $\beta-1.3$ glucanase enzyme, it being this higher in nine times when compared the treatment control. The SA acted in the Fusarium sp. in vitro control with fungitoxic action, suppressed mycelial growth in $28 \%$ if compared to control.

Key words: Beta vulgaris L, elicitor, induced resistance, protein-PR
\end{abstract}

\section{Resumo}

O tombamento de plântulas é a principal doença que afeta a cultura da beterraba no processo de produção de mudas. Objetivou-se neste trabalho avaliar diferentes concentrações de ácido salicílico (AS) na indução de resistência ao tombamento de plântulas de beterraba e a atividade antifúngica contra Fusarium sp., in vitro. $\mathrm{O}$ tratamento das sementes de beterraba foi realizado com imersão em solução de AS nas concentrações de 0,$5 ; 1,0 ; 1,5$ e $2,0 \mathrm{mM}$ e a testemunha (água destilada). Em seguida foram semeadas em substrato previamente esterilizado e inoculado com Fusarium sp. O experimento foi conduzido por 14 dias em câmara de cultivo com controle de temperatura $\left(23^{\circ} \mathrm{C} \pm 2{ }^{\circ} \mathrm{C}\right)$, luminosidade (fotoperíodo de $12 \mathrm{~h}$ ) e umidade $(70 \% \pm 10 \%)$. Após esse período foram avaliados a germinação das

\footnotetext{
1 Engos Agros, Discentes do Curso de Pós-Graduação em Agronomia, Universidade Tecnológica Federal do Paraná, UTFPR, Pato Branco, PR, Brasil. E-mail: douglas bertoncelli@hotmail.com; ritadserrao@hotmail.com

2 Eng ${ }^{\text {os }}$ Agr ${ }^{\text {os }}$, Profs. Drs., Curso de Agronomia, UTFPR, Dois Vizinhos, PR, Brasil. E-mail: sergio@utfpr.edu.br; americowagner@ utfpr.edu.br

3 Discentes do Curso de Agronomia, UTFPR, Dois Vizinhos, PR, Brasil. E-mail: adriano.lewandowski@hotmail.com; nean. locatelli@hotmail.com

* Author for correspondence
} 
sementes, incidência de tombamento, comprimento de plântula e massa da matéria fresca. Foi também avaliada nos tecidos das plântulas a atividade das enzimas fenilalanina amônia-liase (FAL), $\beta$-1,3glucanase e quitinase. No experimento in vitro o AS foi incorporado ao meio BDA (batata-dextrose e ágar) e avaliado o crescimento micelial de Fusarium sp. A aplicação de AS em tratamento de sementes não atuou significativamente sobre o tombamento de plântulas de beterraba, mas induziu a atividade da enzima $\beta$-1,3-glucanase, sendo esta aumentada em nove vezes em relação à testemunha. $\mathrm{O}$ AS atuou no controle de Fusarium sp, in vitro com ação fungitóxica, com supressão do crescimento micelial em $28 \%$ se comparado à testemunha.

Palavras-chave: Beta vulgaris L, eliciador, indutor de resistência, proteína-RP

\section{Introduction}

The beet (Beta vulgaris L.) is a species of plant of the Chenopodiaceae family. Their geographical distribution extends from Eastern India reaches the West, heading towards West of the Canary Islands and the western coast of Europe, including the British Islands and Denmark (FONTES, 2005).

In Brazil, its cultivation was intensified with the European and Asian immigration. In recent decades the area cultivated with this tuberous vegetable shows a great increase, especially in the Southeast, where $42 \%$ of the producing properties are found (FONTES, 2005). In the State of Paraná the cultivated area represents 3,527 ha, with a production of 92,881 tons (IBGE, 2012).

The beet culture presents susceptibility to various diseases during its cultivation, in particular to the damping off of seedlings caused by Fusarium sp. This disease causes depressed lesions in young plant tissues that cause the damping off of the seedling, but it may also occur before the emergence of the plant, showing a reduction at the booth of seeding, in this case presented damping-off in preemergence. Alternative methods for disease control stand through the use of inductors or elicitors that induce plant resistance to pathogens (MAZARO et al., 2009; KUHN; PASCHOLATI, 2010).

The induction of resistance is defined as the activation of a state of resistance against diseases, it being systemically induced in plants by the use of biotic or abiotic external agents, without any change in the genome of the plant, these being called elicitors (EDREVA, 2004; BOSTOCK et al., 2014).
Salicylic acid (SA) is an elicitor with the physiological role of analyzing in plants, especially in the defense against pathogens, it being transported via the phloem to the non-infected plant parts, mainly in the form of methyl salicylate and even serving as a signal to neighbouring plants (MARTINEZ et al., 2000).

Research with plants with mutant genes show that SA regulates the resistance mechanisms at the site of infection (hypersensitivity response HR) and through the systemic acquired resistance through (SAR), acting in the expression of genes responsible for the accumulation of reactive oxygen species in the apoplast, which cause the death of cells in the site of infection, through the synthesis of lignin in the cell wall of neighboring cells in the site of infection and through the synthesis of proteins related to pathogens (PR-proteins) and phenolic compounds in distant sites of infection (GRÜNER et al., 2003; JALALI et al., 2006; VLOT et al., 2009).

The systemic acquired resistance is characterized by the expression of genes which encode various defense responses to pathogens in plants, such as PR-proteins, it being the main ones the chitinases and the $\beta-1.3$ glucanases. These enzymes can promote the degradation of the cell wall of fungi, which formed by $\beta-1.3$ glucan polysaccharides and chitin, which are substrates for $\beta-1.3$ glucanase and chitanases (DURRANT; DONG, 2004). It is also involved in this process of plant defense the phenylalanine ammonia-lyase enzyme (PAL). The PAL is an enzyme involved in the route of shikimic acid, or also called the from phenylpropanoid, being 
the main route of formation of phenolic compounds. It acts in L-phenylalanine deamination, forming trans-cinnamic acid and ammonia. The transcinnamic acid can be incorporated into different phenolic compounds (4-coumaric acid, caffeic acid, ferulic acid), which are present in the formation of esters, coumarins, flavonoids and lignins (CAVALCANTI et al., 2005).

A despite of to know in cientific works the inductor acido salicilico effects, no works have been found on the tipping control of damping-off of beet seedlings. Thus, research is needed that may contribute with information related to the use of the in this pathosystem.

The objective of this study was to evaluate different concentrations of salicylic acid (SA) in the induction of resistance to damping-off of beet seedlings and antifungal activity against Fusarium sp. in vitro.

\section{Material and Methods}

The experiments were carried out at the Federal Technological University of Paraná - Dois Vizinhos campus, and the stage of cultivation conducted in controlled chamber (fitotron system), installed in the Laboratory of Plant Physiology, and the in vitro in the Plant Pathology Laboratory in the same institution, in the year of 2014.

The seed treatment was performed with the their immersion in the SA solution for 5 minutes at the concentrations of $0.5 ; 1.0 ; 1.5$ and $2.0 \mathrm{mM}$ and the control (distilled water) in completely randomized design with four replications. Subsequently, they were sown in expanded polystyrene trays containing the Plantamax Florestal $^{\circledR}$ substratum previously sterilized and inoculated with Fusarium sp. Each repetition was made up of 20 cells, where each cell received a seed treated with the inductor.

The mycelium of Fusarium sp. was previously inoculated into autoclaved wheat seeds, being kept in an B.O.D. incubator. Those seeds of wheat contaminated with Fusarium sp. were used as a vehicle to the sterilized substratum contaminant, in the proportion of $10 \mathrm{~g} \mathrm{~kg}^{-1}$. Inoculants were incorporated into the substratum three days before receiving the seeds.

The trays were maintained in a $2.5 \mathrm{~m}$ length $\mathrm{x}$ $2.5 \mathrm{~m}$ width $\times 2.50 \mathrm{~m}$ height cultivation chamber, under temperature control $\left(23^{\circ} \mathrm{C} \pm 2^{\circ}\right)$, light (photoperiod of 12 hours) and humidity $(70 \% \pm$ $10 \%$ ). After 14 days the experiment was completed, by analyzing the variables, seed germination, incidence of damping-off, seedling length and mass of fresh matter. In control treatments and in higher concentration of SA $(2.0 \mathrm{mM})$ were also quantified, in the tissues of seedlings, the levels of enzymes phenylalanine ammonia-lyase (PAL), $\beta$ -1.3 glucanase and chitinase, and that the samples were constituted by $0.5 \mathrm{~g}$., merged among all parts of the plant (leaves, stem, and roots), which were, immediately after collection, frozen and stored in liquid nitrogen until the assessments.

The percentage of emergency was assessed by the number of germinated seedlings, taking into account the total percentage of 20 seeds per repetition. The percentage of damping-off was considered by the number of seedlings that showed symptoms of the disease. The seedling size was determined with a caliper. The mass production of total fresh matter (aerial part and roots) of seedlings was evaluated in a precision scale.

The determination of the activity of phenylalanine ammonia-lyase (PAL) was by colorimetric quantification of trans-cinnamic acid released from the substrate phenylalanine as per the methodology described by Kuhn (2007), with adjustments, where they were $0.25 \mathrm{~g}$ of the sample with more $3.0 \mathrm{~mL}$ of TRIS-HCl pH 8.0 buffer. This extract was packaged in micro tubes and centrifuged for $10 \mathrm{~min}$ at $4^{\circ} \mathrm{C}$ at $6500 \mathrm{~g}$. A portion of $200 \mu 1$ was transferred to another test tube, by adding more 3.0 $\mathrm{mL}$ of extraction buffer. The solution was stirred in vortex, thus obtaining the enzymatic extract. 
This extract, $1.5 \mathrm{~mL}$ was transferred to another test tube, with over $1.0 \mathrm{~mL}$ of the extraction buffer and $0.5 \mathrm{~mL}$ of phenylalanine. This solution was again stirred in vortex for homogenization. After being removed from the water bath, the tubes were placed in an ice bath for 5 minutes to stop the reaction and thus enabling a reading in the spectrophotometer at $290 \mathrm{~nm}$.

For the dosing of chitinase and $\beta-1.3$ glucanase activities were carried out the procedures described by Wirth and Wolf (1992), with adjustments, and the samples were macerated in $2.0 \mathrm{~mL}$ of $100 \mathrm{mM}$ acetate buffer (pH 5.0), with subsequent centrifugation $(20.000 \mathrm{~g}$ for $25 \mathrm{~min}$. at $-4^{\circ} \mathrm{C}$ ). The supernatant was collected and used for the evaluation of the activity of enzymes. The enzymatic activity of chitinase was evaluated through the release of soluble oligomers of "chitinazure", from chitin carboximetilada marked with brilliant violet remazol 5R-RBV (Sigma Aldrich ${ }^{\circledR}$ ). For the spectrophotometric determination of $\beta-1.3$ glucanase activities in the extracts was used as curdlan-remazol brilliant blue substratum (Sigma Aldrich $^{\circledR}-4$ mg.ml ${ }^{-1}$ ).

The in vitro experiment was conducted in the Laboratory of Phytopathology of the UTFPR Dois Vizinhos Campus, being used in concentrations of $0.5 ; 1.0 ; 1.5$ and $2 \mathrm{mM}$ of SA, plus a control containing distilled water. The experimental design used was the completely randomized design with four replications.

The inductor was incorporated into the B.D.A culture medium, with electromagnetic stirrer to homogenize the mixture. Then the culture medium was poured into Petri ${ }^{\circledR}$ plate, in the laminar flow chamber. After the solidification of the medium, they were placed in $10 \mathrm{~mm}$ diameter disks, containing the mycelium of Fusarium sp., on the plates, with their concentrations of the inductor. Subsequently, the plates were kept in B.O.D. at a temperature of $25^{\circ} \mathrm{C} \pm 1^{\circ} \mathrm{C}$ and a photoperiod of 12 hours.

The mycelial growth was monitored during 18 days after incubation in B.O.D, and it was finalized at this time because the Petri ${ }^{\circledR}$ plates controls having their edges affected by the mycelial growth of Fusarium sp.

Data were evaluated to analysis of variance $(p$ $\leq 0.05$ ) and, when significant, it was submitted to regression analysis, with the adoption of the $5 \%$ level of significance, using the ASSISTAT program (SILVA; AZEVEDO, 2009).

\section{Results and Discussion}

The results showed that treatment of beet seed with no significant interference resulted in seed germination, incidence of seedling damping-off and on the their length (table 1).

Table 1. Seed germination, incidence of damping-off and length of seedlings subjected to the beet seed treatment with salicylic acid (SA) and the inoculation of Fusarium sp. Dois Vizinhos, 2014.

\begin{tabular}{cccc}
\hline $\begin{array}{c}\text { SA concentration } \\
(\mathbf{m M})\end{array}$ & $\begin{array}{c}\text { Germination } \\
\mathbf{( \% )}\end{array}$ & $\begin{array}{c}\text { Incidence } \\
\mathbf{( \% )}\end{array}$ & $\begin{array}{c}\text { Seedlings length } \\
(\mathbf{c m})\end{array}$ \\
\hline 0 & $92,50^{\text {ns }}$ & $7,50^{\text {ns }}$ & $7,972^{\text {ns }}$ \\
0,5 & 95,00 & 5,00 & 10,915 \\
1,0 & 96,25 & 3,75 & 9,065 \\
1,5 & 97,50 & 2,50 & 8,365 \\
2,0 & 96,25 & 3,75 & 8,955 \\
\hline
\end{tabular}

$\mathrm{ns}=$ non-significant at the $5 \%$ level by test $\mathrm{F}$. 
Considering the results in relation to seed germination it was observed that non-phytotoxic effect presented about the germinating process. Such information is important, considering that with an inhibitory effect on germination, this could limit the use of the product as the resistance inducer of beet seed treatment, a fact commented by Silveira et al. (2000), working with salicylic acid on rice seeds, where it was verified that the SA in concentrations of $0.1 ; 0.5 ; 1.0 ; 10$ and $20 \mu \mathrm{M}$ had an inhibitory effect on germination, it being most evident at 10 and $20 \mu \mathrm{M}$ concentrations, these being phytotoxic in all tests made.

As for germination, the incidence of dampingoff has not presented statistical difference in function of seed treatment with SA. In the control, the incidence values were higher, compared to other treatments, but in general the incidence was low, considering the aggressiveness of the inoculated pathogen and favorable environmental conditions. In this sense, it can be seen in this pathosystem the effect on damping-off of seedlings, a fact that does not rule out the action on the induction of resistance. The function attributed to SA on the plant is like a signaling molecule, by inducing the expressing resistance against pathogen attack. Exogenous applications of induce gene expression of proteins involved in the induction of systemic acquired resistance, considering the proposition of the role of the endogenous in disease resistance (CHET, 1993), by the expression of proteins related to pathogenicity (CAMPOS, 2009).

The treatment with SA did not interfere in the seedling length parameter, it being positive, because that it demonstrates that besides there was no phytotoxic damage to seedlings, there was no loss by metabolic diversion of route to plant defense. Metabolic loss occurs primarily by the use of erythrose-3-phosphate pentose cycle substratum, or phosphoenolpyruvate of glycolysis in the path of the phenylpropanoid, this being one of the main routes of plant defense, and thus such substrates will no longer be used in the process of plant growth. In bean plants using the acibenzolar-Smethyl resistance inducer, analogous to SA changed the plant metabolism generating metabolic cost and redirectioning of photoassimilated to invest in defense, with cost of reduced productivity (KUHN, 2007). Yet Heil et al. (2000) state that production of PR-proteins can compete with proteins necessary for the basic processes of the plant, which may compromise its growth.

On the other hand, the beet seeds treatment with SA submitted to inoculated substractum with Fusarium sp., resulted in a linear increase in the fresh mass matter (MFM) with increasing concentrations (Figure 1). Possibly, such a result is related to the effect of SA on the hormonal activity of plants. SA has been studied for its effect on several physiological processes related to the growth and development of plants under normal conditions, and it can even be included in the category of phytohormones (VIEIRA, 2011). Among these effects are the stimulation of root growth, closing of stomata and reduced transpiration (LARQUESAAVEDRA, 1979). In addition, it can reduce the synthesis of ethylene plants, slowing the effects of this hormone, as it can reduce the activity of ACCoxidase, the enzyme precursor for its synthesis (ALTVORST; BOVY, 1995).

The application of the beet seed did not significantly change the activity of the enzyme phenylalanine ammonia-lyase and chitinase of beet seedlings subjected to substrate inoculated with Fusarium sp. (Figure 2 A and B). In turn, the activity of the $\beta-1.3$ glucanase enzyme was increased with the application of $2 \mathrm{mM}$ of SA in beet seeds (Figure 2 C). 
Figure 1. Fresh mass matter (g) of sugar beet seedlings subjected to treatment of seeds with salicylic acid (SA), and inoculated with Fusarium sp. Dois Vizinhos, 2014.

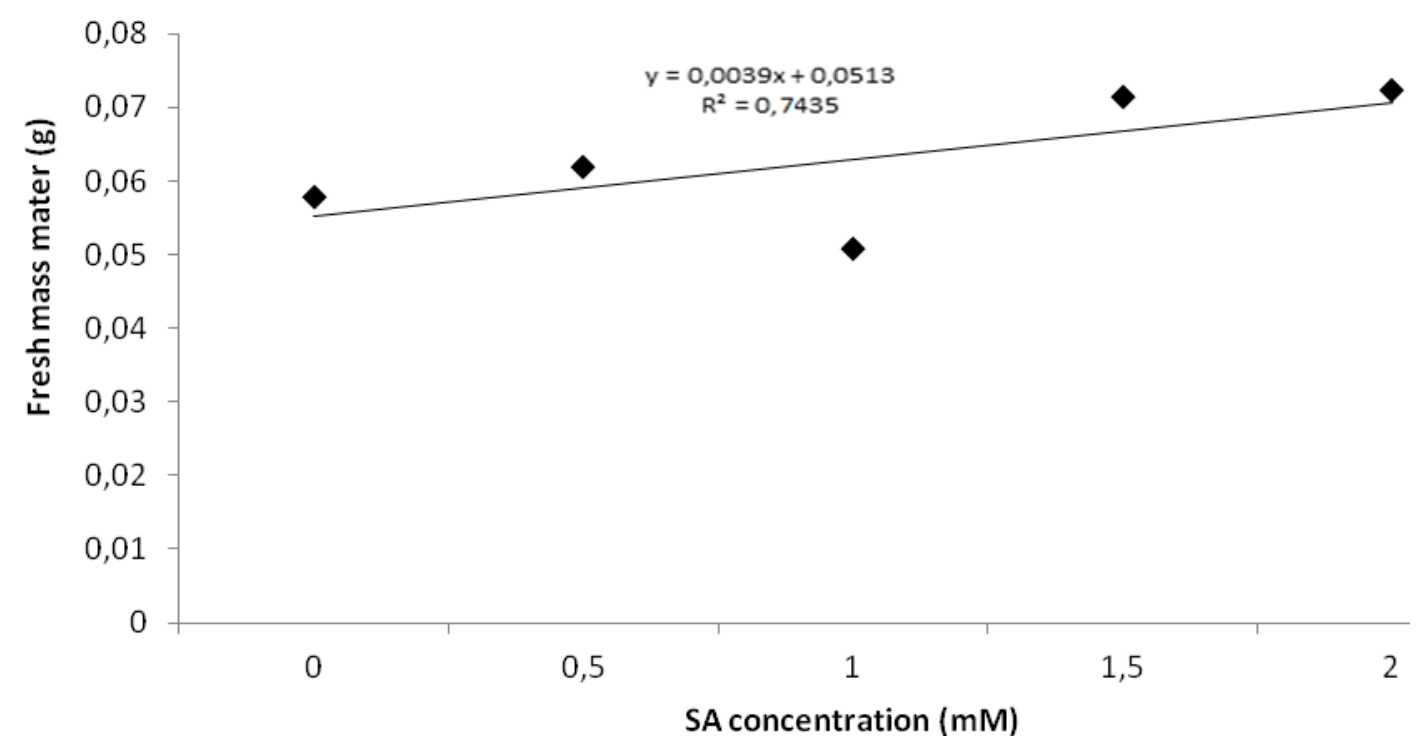

Figure 2. A. Activity of the phenylalanine ammonia-lyase (PAL) enzyme, B - Activity of the chitinase enzyme, $\mathbf{C}$ - Activity of $\beta-1.3$ glucanase enzyme in seedlings subjected to the beet seed treatment with salicylic acid (SA) and inoculated with Fusarium sp. Dois Vizinhos, 2014.

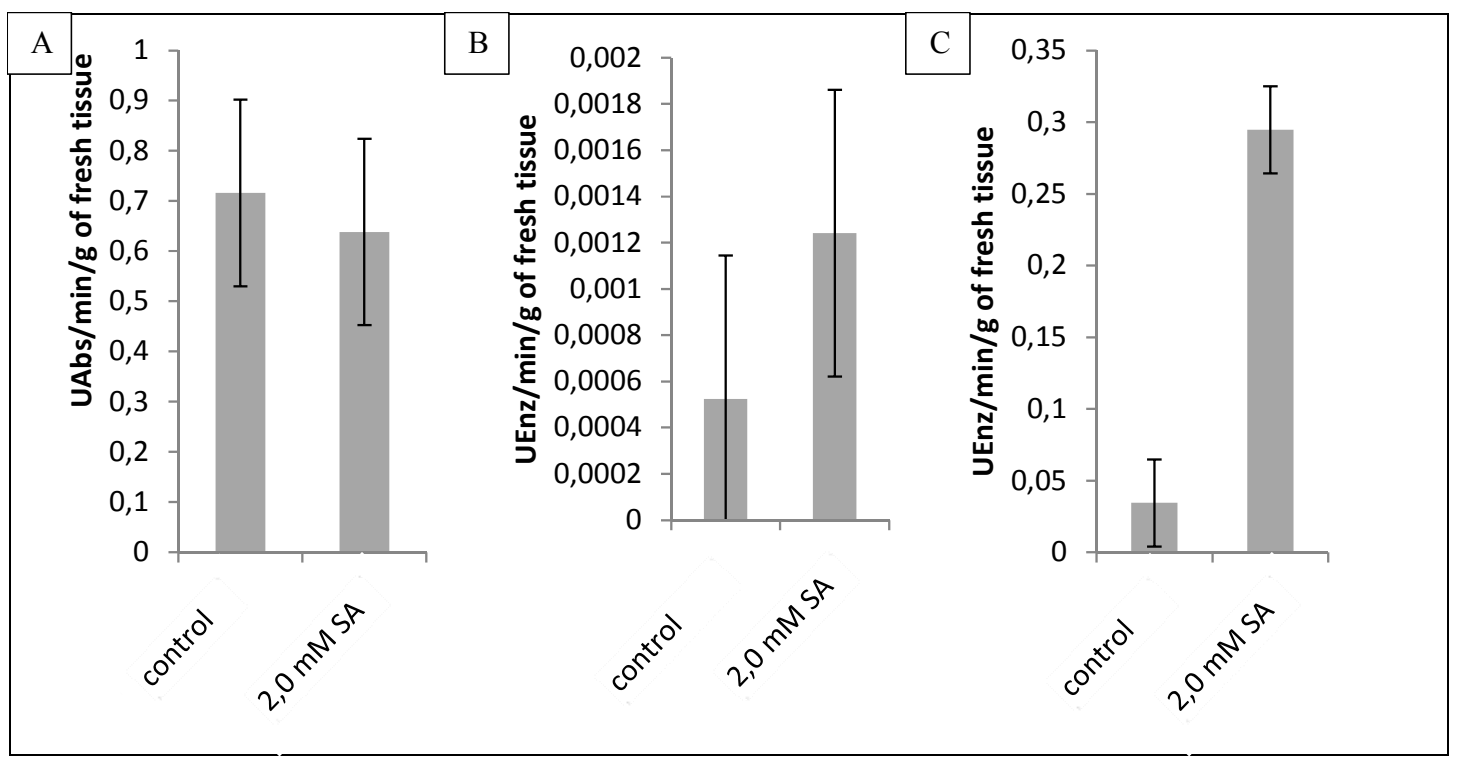

These results demonstrate that SA plays in inducing resistance, on a preferred basis form by activating the $\beta-1.3$ glucanase. It should be emphasized that the $\beta-1.3$ glucan polysaccharide is an important component in the cell wall of many fungi, which are substrate for the $\beta-1.3$ glucanase (WESSELS; SIETSMA, 1981).
In the same way as the observed in this work, other authors also found relating to application of the activity of $\beta-1.3$ glucanase, and in bean plants, the sprinkling of salicylic acid at $0.01 \mathrm{M}$, at the V2 stage, elevated glucanases and quitinases activity, which resulted in lower severity of disease caused by the fungus Colletotrichum lindemuthianum (CAMPOS 
et al., 2009). In turn, in bean plants treated with SA and infected by Sclerotinia sclerotiorum, there was an increase in the activity of $\beta-1.3$ glucanase (INOCÊNCIO et al., 2009).
In the $\mathrm{t}$ work in vitro the salicylic acid (SA) decreased the mycelial growth of Fusarium sp. Such suppression had descending linear behavior with increasing concentrations (Figure 3).

Figure 3. Mycelial growth of Fusarium sp. submitted to the application of increasing concentrations of salicylic acid (SA) in the culture medium. Dois Vizinhos, 2014.

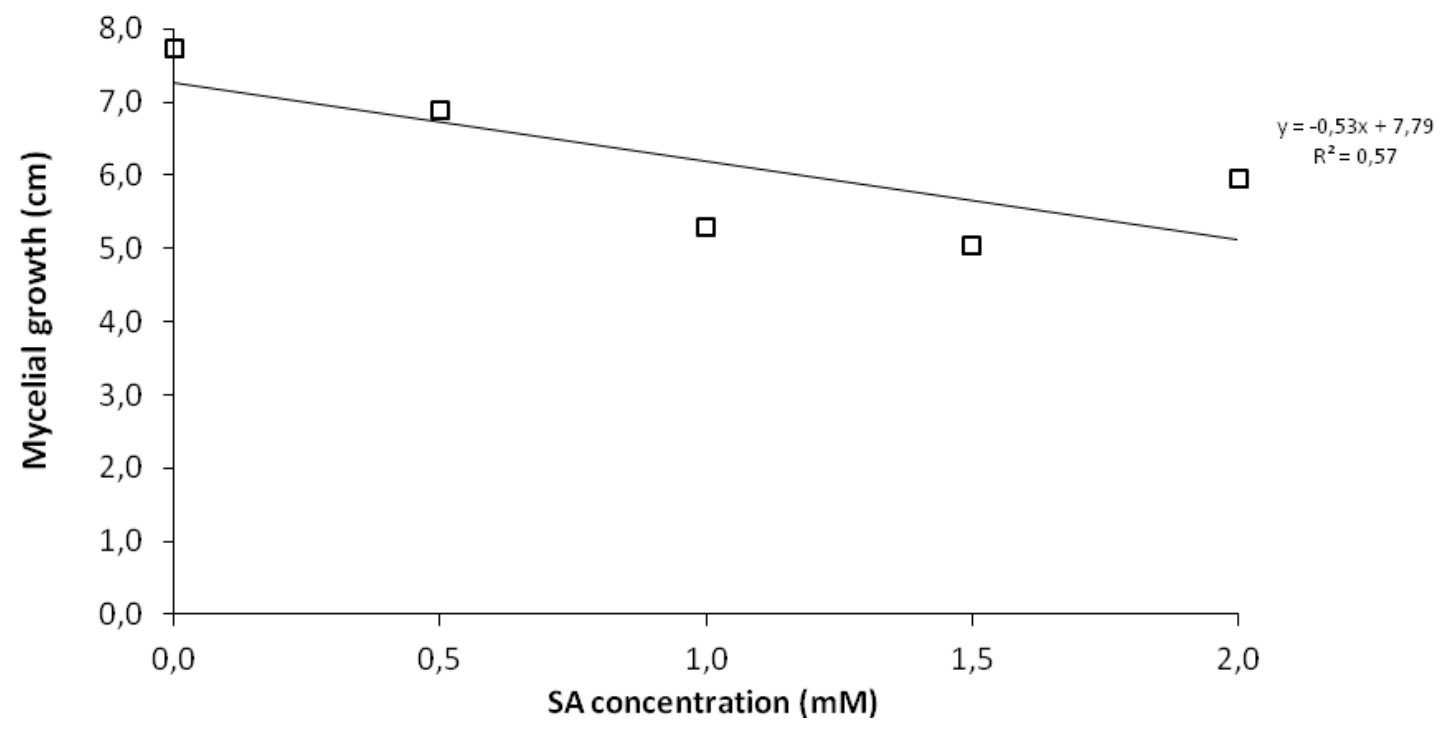

This result corroborates with those found by $\mathrm{Yu}$ and Zheng (2006), that working with salicylic acid and yeasts against Penicillium expansum fungus, has shown that salicylic acid presented in vitro fungicide effect when applied at concentrations greater than $0.6 \mathrm{mM}$, due to their direct contact with the pathogen.

It is believed that this fungitoxic capacity of the is related to the fact of this being a phenolic compound, which may have direct action on the pathogen, fungitoxic acting on cellular multiplication speed or direct the cell of the pathogen. In this sense, Lo et al. (1996) state that the phenolic compounds present fungitoxic, antibacterial and antivirotical activities, and this inhibitory effect acts mainly on spore germination, mycelial growth, production and activation of microbial enzymes, by varying its action among the different groups of phenols (STANGARLIN et al., 2011).
By evaluating the data all together, it can be affirmed that SA acts in two ways, by inducing resistance in beet seedlings, such induction being proven by the activation of the $\beta-1.3$ glucanase enzyme and also by the fungitoxic action on the pathogen.

Due to the potential of SA, new works are suggests considering other phytopathogenic involved in damping-off of seedlings, inoculum pressure and field conditions.

\section{Conclusions}

The SA application for beet seeds treatment does not interfere significantly in the seedlings dampingoff, but it induces resistance by activating the $\beta-1.3$ glucanase enzyme.

The SA had fungitoxic action in vitro against Fusarium sp. 


\section{References}

ALTVORST, A. C.; BOVY, A. G. The role of ethylene in the senescence of carnation flowers: a review. Plant Growth Regulation, New York, v. 16, n. 1, p. 43-53, 1995.

BOSTOCK, R. M.; PYE, M. F.; ROUBTSOVA, T. V. Predisposition in plant disease: Exploiting the nexus in abiotic and biotic stress perception and response. Annual Review of Phytopathology, Davis, v. 52, n. 1, p. 23-33, 2014.

CAMPOS, A. D. Considerações sobre indução de resistência a patógenos em plantas. Pelotas: Embrapa Clima Temperado, 2009. 28 p. (Documentos, 264).

CAMPOS, A. D.; HAMPE, M. M. V.; FERREIRA, A. G.; ANTUNES, I. F.; CASTRO, L. A. S. Indução de resistência sistêmica à antracnose em feijoeirocomum pela raça delta avirulenta de Colletotrichum lindemuthianum. Pesquisa Agropecuária Brasileira, Brasília, v. 44, n. 1, p. 15-21, 2009.

CAVALCANTI, L. S.; PIERO, R. M.; CIA, P.; PASCHOALATI, S. F.; RESENDE, M. L. V.; ROMEIRO, R. S. Indução de resistência a patógenos e insetos. Piracicaba: FEALQ, 2005. 263 p.

CHET, I. Biotechnology in plant disease control. New York: Wiley-Liss, 1993. 373 p.

DURRANT, W. E.; DONG, X. Systemic acquired resistance. Annual Review of Phytopathology, Palo Alto, v. 42, n. 1, p. 185-209, 2004.

EDREVA, A. A novel strategy for plant protectioninduced resistance. Journal of Cell and Molecular Biology, v. 3, n. 2, p. 61-69, 2004.

FONTES, P. C. R. (Ed.). Olericultura: teoria e prática. Viçosa, MG: Editora UFV, 2005, 486 p.

GRÜNER, R.; STROMPEN, G.; PFITZNER, A. P.; PFITZNER, U. M. Salicylic acid and the hypersensitive response initiate distinct signal transduction pathways in tobacco that converge on the as-1-like element of the PR-1a promoter. European Journal of Biochemistry, Stuttgart, v. 270, n. 24, p. 4876-4886, 2003.

HEIL, M.; HILPERT, A.; WERNER, K.; LINSENMAIR, K. E. Reduced growth and seed following chemical induction of pathogen defence: does systemic acquired (SAR) incur allocation costs? Journal of Ecology, Londres, v. 88, n. 1, p. 645-654, 2000.

INOCÊNCIO, A. P. M.; OLIVEIRA, M. B.; SANTOS, E. M.; NASCIMENTO, L. B.; ALVES; E. B.; SOARES, D. A.; LOBO JÚNIOR, M.; SILVA, S. P. Indução de resistência em planta de feijoeiro infectada por Sclerotinia sclerotiorum. In: CONGRESSO
BRASILEIRO DE MICROBIOLOGIA, 25., 2009, Porto de Galinhas. Anais... São Paulo: Sociedade Brasileira de Microbiologia, 2009. 1CD-ROM.

INSTITUTO BRASILEIRO DE GEOGRAFIA E ESTATÍSTICA - IBGE. Produção Agrícola Municipal 2008. Sistema IBGE de recuperação automática, Sidra, 2012. Disponível em: <http://www.ibge.gov.br/ home/presidencia/noticias/noticia_visualiza.php?id_ noticia $=740>$. Acesso em: 5 maio 2012 .

JALALI, B. L.; BHARGAVA, S.; KAMBLE, A. Signal transduction and transcriptional regulation of plant defense responses. Journal of Phytopathology, Pune, v. 154, n. 2, p. 65-74, 2006.

KUHN, O. J. Indução de resistência em feijoeiro (Phaseolus vulgaris) por acibenzolar-S-metil e Bacillus cereus. Aspectos fisiológicos, bioquímicos e parâmetros de crescimento e produção. 2007. Tese (Doutorado em Fitopatologia) - Escola Superior de Agricultura Luiz de Queiroz. Universidade de São Paulo, Piracicaba.

KUHN, O. J.; PASCHOLATI, S. F. Custo adaptativo da indução de resistência em feijoeiro mediada pela rizobactéria Bacillus cereus ou acibenzolar-S-metil: atividade de enzimas, síntese de fenóis e lignina e biomassa. Summa Phytopathol, Botucatu, v. 36, n. 2, p. 107-114, 2010.

LARQUE-SAAVEDA, A. Stomatal closour in response to acetylsalicylic acid treatment. Z Pflanzenphysiol, v. 93, n. 4, p. 371-375, 1979.

LO, L. C.; WEIERGANG, I.; BONHAM, C.; HIPSKIND, J.; WOOD, K.; NICHOLSON, R. L. Phytoalexin accumulation in sorghum: identification of a methyl ether of luteolinidin. Physiological and Molecular Plant Pathology, London, v. 49, n.1, p. 21-31, 1996.

MARTINEZ, C.; BACCOU, J. C.; BRESSON, E.; BAISSAC, Y.; DANIEL, J. F.; JALLOUL, A.; MONTILLET, J. L.; GEIGER, J. P.; ASSIGBETSÉ, K.; NICOLE, M. Salicylic acid mediated by the oxidative burst is a key molecule in local and systemic responses of cotton challenged by an avirulent race of Xanthomonas campestris pv. malvacerum. Plant Physiology, Bethesda, v. 122, n. 3, p. 757-766, 2000.

MAZARO, S. M.; WAGNER JUNIOR, A.; SANTOS, I.; CITADIN, I.; POSSENTI, J.; GOUVEA, A. Controle do tombamento de plântulas de beterraba e tomate pelo tratamento de sementes com quitosana. Pesquisa Agropecuária Brasileira, Brasília, v. 44, n. 11, p. 14241430, 2009.

SILVA, F. de A. S.; AZEVEDO, C. A. V. de. Principal components analysis in the software assistat-statistical attendance. In: WORLD CONGRESS ON COMPUTERS 
IN AGRICULTURE, 7., 2009, Orlando, Proceedings... Reno, NV: American Society of Agricultural and Biological Engineers, 2009. 1CD-ROM.

SILVEIRA, M. A. M.; MORAES, D. M.; LOPES, N. F. Germinação e vigor de sementes de arroz (Oryza sativa L.) tratadas com ácido salicílico. Revista Brasileira de Sementes, Londrina, v. 22, n. 2, p. 145-152, 2000.

STANGARLIN, J. R.; KUHN, O. J.; TOLEDO, M. V.; PORTZ, R. L.; SCHWAN-ESTRADA, K. R. F.; PASCHOLATI, S. F. A defesa vegetal contra fitopatógenos. Scientia Agraria Paranaensis. Marechal Cândido Rondon, v. 10, n. 1, p. 18-46, 2011.

VIEIRA, J. G. Aplicação exógena de ácido salicílico no feijoeiro. 2011. Dissertação (Mestrado em Agronomia) Universidade do Oeste Paulista, Presidente Prudente.
VLOT, A. C.; DEMPSEY, D. A.; KLESSIG, D. F. Salicylic acid, a multifaceted hormone to combat disease. Annual Review of Phytopathology, Davis, v. 47, n. 1, p. 177-206, 2009.

WESSELS, J. G. H.; SIETSMA, J. H. Fungal cell walls: a survey. In: TANNER, W.; FA LOEWUS, F. A. (Ed.). Encyclopedia of plant physiology: plant carbohydrates, Berlin: Springer, 1981. v. 138, p. 352-394.

WIRTH, S. J.; WOLF, G. A. Micro-plate colourimetric assay for endo-acting cellulose, xylanase, chitinase, 1,3- $\beta$-glucanase and amylase extracted from forest soil horizons. Soil Biology and Biochemistry, Oxford, v. 24, n. 6, p. 511-519, 1992.

YU, T.; ZHENG, X. D. Salicylic acid enhances biocontrol efficacy of the antagonist Cryptococcus laurentii in Apple fruit. Journal of Plant Growth Regulation, New York, v. 25, n. 2, p. 166-174, 2006. 
